\title{
CHINA-AFRICA COOPERATION IN THE 21st CENTURY: ANALYSIS OF THE OBSTACLES AND CHALLENGES TO GOOD COOPERATION
}

\author{
Kieran E. UCHEHARA \\ At1lım University, Turkey
}

\begin{abstract}
The paper attempts an evaluation of China-Africa cooperation in the $21^{\text {st }}$ century. This engagement cannot be ignored for a variety of reasons. Firstly, it gives Africa leverage in its relations with the North. Secondly, China's emergence onto the global stage compels African government and their counterparts in the South to reflect on and adopt initiatives that address the challenges of globalization. Thirdly, for African policy-makers, a more nuanced understanding regarding the varied impacts that China can have on their economies and on Africa's development path is needed. For pessimists China represents a terrifying threat while for optimists it is a tantalizing opportunity. The key question is whether China's engagements in Africa are purely extractive or have a developmental impact. The paper looks in some detail at these real and possible impacts. It concludes that there are complexity of interactions between Chinese and African trade, investment and aid.
\end{abstract}

Keywords: China, Africa, Partnership, Cooperation, Trade, Investment, Aid, Obstacles and Challenges

\section{INTRODUCTION}

The paper is motivated by the observations that the rapid and sustained expansion of the giant economy of China has been associated with a robust and increasing intensification of its economic relations with various African countries. And that these relationships are, in turn, associated with both opportunities and challenges for African countries. The primary purpose of this paper is to undertake a comprehensive review of literature on the impacts of China on African countries. This paper focuses on trade, investment and aid flows as the key channels through which the impacts of China may be transmitted to an African economy. The question that needs to be addressed then is have the Chinese Cooperation ventures contributed to driving new forces, generating positive spin-off, and serving as effective leapfrogging vehicles for Africa's development in the $21^{\text {st }}$ century? Finally, the paper is based on discourse and literature review of the impact of China on Africa with special emphasis on trade, investment and aid.

\section{Literature Review}

It needs to be underlined at the outset that the establishment of modern China-African relations goes back to 1961. Following Chairman Mao's observation that "We don't have a clear understanding of African history, geography, and the present situation" (Anshan, 2005). From 1963-1964, Prime Minister of the Peoples' Republic of China Zhou Enlai made a ten country visit to Africa. The general 
aim of Premier Chou Enlai's visit to Africa were to: 1) underscore the implementation of the OneChina policy and foreclose Taiwan's diplomatic relations with Africa, 2) respect the principles of sovereignty and non-intervention, 3) promote development on the basis of equality and mutual benefit, 4) seek prestige by presenting itself as mentor or a de facto leader or a moral leader of the developing world in the United Nations, and 5) de-link the progressive African nations from the hegemonic relations they had with the then-revisionist Soviet Union, and 6) sow anti-Western imperialist sentiments in Africa (Muekalia, 2004: 5-12; Harris, 1985). Prior to the 1970s, China-African relations were by and large ideologically driven. It provided financial support, equipment and training to a variety of liberation movements, particularly in Algeria, Angola, Congo, Mozambique, Namibia, South Africa, Rhodesia, etc. China's "involvement in the Non-Aligned Movement and other Third World conference type activities, were designed to demonstrate its own anti-imperialist approach to aid and to identify it with those nations that continued to suffer the effects of colonialism (Hamrin, 1986).

Gu and Humphrey blame Africa's underdevelopment on colonialism. Beijing believes it has established the moral ground. From training "fighter for freedom" in the revolutionary 1960s and early 1970s to providing scholarships to children of African elites, China has been exporting its values for years. By successfully linking neo-colonialism with the neo-liberalism of Western countries, China has been able to win the hearts and minds of African elites ( $\mathrm{Gu}$, and Humphrey, 2006). To exemplify its commitment to a non-imperialist stand, starting in 1967, China began building the Tanzam Railway between Tanzania and Zambia. Following the death of Moa Zedong, however, the Chinese government gave less attention to Africa. Instead, China turned inward throughout the 1980 and 1990 to experiment with its new economic reform programs.

"When Chinese economic reform began in 1978, the political leadership initially concentrated on a swift economic catching-up process, and attracted only relatively little importance to Africa in comparison with Western industrialized countries and Japan. For instance, between 1980 and 1987 the contribution pledged each year amounted to about \$200-300 million, falling to a low point in 1988 of only $\$ 60.4$ million. This comparatively low status was reflected in the rather sporadic visits by high-ranking politicians to Africa, a stagnating volumes of trade, and stagnating or even declining development assistance inputs" (Asche, 2008).

Because of the global domination by the World Bank and International Monetary Fund's structural adjustment programs (which advocated extensive economic liberation and privatization), the ChinaAfrican relations were partially eclipsed during the Cold War. Following the Tiananmen incident of 1989 (under the economic transformation initiated by President Deng Xiaoping), China renewed its engagement with Africa and referred to it as the Beijing Consensus. In order to feed its blooming economic need for resources (oil, minerals, timber, etc.) and to market its manufactured goods in Africa, China resumed its economic relations with Africa through an institutional framework known as the Forum on China-Africa Cooperation (FOCAC). In contrast to the West's view of Africa that chaos, conflict, corruption, and poor governance characterize its underdevelopment, China propagates that the African continent is rich in culture, religion, social dynamism, and energy. Realizing that the African continent has a great opportunity for business, the Chinese government encourages the following industries and projects to be invested in Africa: a) processing industrial products in the fields of electronics, machinery building, textiles, and garments, b) investing in agricultural products in order to add value to Africa's exports and improve Africa's terms of trade, c) extracting natural resources, such as petroleum and high-value minerals, and d) investing in infrastructure, power supply, and real estate development (UNDP, 2007). 


\section{Foreign Direct Investment}

Realizing that Africa is marginalized in the worldwide distribution of foreign direct investment (FDI), China pledged government-backed foreign direct investment to African countries. In 2007, over 700 registered Chinese state-owned and private companies (provided with government financial backing) have entered into a number of business ventures in collaboration with African national governments, state-owned corporations, and private firms. For instance, the Chinese government has designated about 180 companies to benefit from preferential finance, tax concessions, and political backing to "go global" and become true multinationals (Alden and Davies, 2006). Despite the government's support in leveraging Chinese businesses to go global, at this stage, Chinese investment in Africa is very low in comparison with other areas. For example, "Africa is attracting less investment, ranking in a mere US\$317 million corresponding to 5.8\% of total Chinese FDI outflows in 2005, in comparison to Latin America, which attracted US $\$ 1.7$ billion accounting for $32 \%$. Asia pulled off US\$3 billion, representing 54.6\% of total Chinese FDI outflows" (Rocha, 2008, p. 58). Though the motives of foreign direct investments might be 1) securing new markets, 2) raising efficiency, 3) securing raw materials, 4) obtaining cheap labor, and 5) securing defensive or offensive strategic advantages, the Chinese investments in Africa seemed be exclusively focused on securing raw materials and developing the markets for Chinese goods and services.

\section{Aid to the African Continent}

The basic forms of the Chinese Development Cooperation, which is almost exclusively projectbased, includes 1) giving grant aid (non-repayable loans to social projects such as schools, hospitals, housing, etc), 2) interest-free loans to finance infrastructure projects, and 3) preferential credits or concessionary credits (reserve-backed lending) with interests rates below the market level. Through the Export and Import (EXIM) Bank of China (the official credit agency of China established in 1994 to extend export buyer credits, export seller credits, and credits for investment, construction projects, and guarantees to promote Chinese investment in Africa), it lends to China's state-owned enterprises (SOEs) to promote their "Going Global" strategy. Though there is no distinction between development cooperation and commercial cooperation, the EXIM bank mainly assists the financing of infrastructures regarded very vital for extracting and transporting energy and mineral resources. According to Corkin and Burke, China's "state capital" approach to engagement through the likes of the EXIM Bank is answerable to political stakeholders, not private or institutional shareholders expecting short-term gains as in Western countries. The Chinese EXIM Bank, founded in 1994, is wholly owned by the state and operates under the central government. With the China Development Bank (CDB) and the China Agriculture Development Bank, the EXIM Bank is "tasked to promote exports and foreign investment. Its export credits focus on infrastructure (roads, power plants, oil and gas pipelines, telecommunications, and water projects); its investment loans target the energy, mining, telecommunication, industrial, and water projects. The bank's main source of funding is the bond market. Unlike export credit agencies in other countries, the government does not guarantee the bank's liabilities (Jiane-Ye, 2007).

The EXIM Bank allows Chinese state-owned companies to invest in large-scale projects with returns that might emerge in the long-term. But all Chinese exports and investment abroad are insured against buyer and country risks, that is, foreign exchange restrictions, expropriation, nationalization, and war. "According to the requirements of China EXIM Bank, in principle, all contractors and exporters linked to the contract funded by a China EXIM Bank loam should be Chinese and 50\% of all 
procurements should be from China. Such conditions give the Chinese companies advantage in terms of new market entry (Corkin and Burke, 2008: 43). By 2005, the Chinese EXIM Bank's portfolio had "tripled and its commercial operations outstripped those of its counterparts in the US, UK, and Japan" (Moss and Rose, 2007). As a result, in terms of exports and imports, China has established itself as one of Africa's most important trading partners after the USA and is likely to have overtaken all the former European colonial powers in 2007 (Asche, 2007). Nonetheless, it needs to be underlined that unlike the South-South cooperation which is based on the motto of exchanging industrial and non-industrial countries among the South partners, China exports mainly manufactured goods to African countries and the African countries on the other hand supply crude oil, minerals (iron ore, steel, copper, magnesium, diamonds), timber and agricultural products to China (China Commerce Year book, 2007).

\section{Trade}

Using preferential trade as a window of opportunity for the development of Africa and opening new markets for Chinese exported goods, China has offered sizeable loans to various African countries. By the end of 2005, China's EXIM Bank approved loans worth US\$6.5 billion for 260 projects in 36 African countries. But concessional and low-interest loans for infrastructure development amounted to US\$12.5 billion. At the FOCAC summit in November 2006, President Hu Jintao announced that China would double its assistance by 2009 , provide US $\$ 3$ billion in preferential loans and US $\$ 2$ billion in preferential buyer's credits to Africa. It has eliminated tariffs on a number of products that are exported by African countries (le Pere, 2008: 15). It needs to be highlighted that the Chinese government chooses Chinese construction companies to undertake large-scale projects and infrastructure development to encourage the expansion of markets and the entry of smaller firms in Africa. For instance, as of September 2006, China's committed 79 percent of its contracted investment in infrastructure development (Ellis, 2007). Between 2000 and 2005, China-Africa trade was $\$ 39$ billion and is projected to reach $\$ 100$ billion by 2010 (Alden, 2005). Since 2000, Africa's exports to China have grown at a rate of 56 percent. Oil and mineral exports account for 85 percent of African exports to China. "The share of Africa's exports to China rose from 1.3\% in 1995 to $9.3 \%$ in 2004, accompanied by a significant decline in African exports to OECD countries in the same period" (The Broker, 2007).

\section{Development Assistance and Soft Loans}

In its socially responsible development programs, China is donating development assistance and soft loans to various African states to finance their infrastructure projects, including roads, railways, access to fishing waters, hydropower stations, agricultural land, schools, and medical personnel. In 2006 alone:

"There were more than 1000 Chinese doctors and nurses working in 36 African countries. At the Beijing Summit, Hu Jintao also announced support for 30 new hospitals in Africa, 30 malaria prevention and treatment centres and an additional US $\$ 38$ million for the provision of artemisinin (a derivative of the Artemissia shrub) over the next years. By 2009, the government scholarships for African students to study in China is said would be doubled from their present 2000; and 15,000 African professionals will be trained in technical, scientific and administrative fields in 2007-2009" (le Pere, 2008: 15). 
In addition, "with 26 African countries now being accorded 'Approved Destination Status' by China, it is projected that there will be 1 million Chinese tourists traveling to Africa by 2020, compared to the 110,000 in 2005" (le Pere, 2008. 18). In short, in contrast to Western hegemonies, China's bilateral state-centric engagement in Africa is based on the principles of sovereignty and non-interference in internal affairs. China's investment in Africa is driven to: 1) acquire the need for natural resources, energy supplies, and export markets to sustain its growing economy. Also, as stated by Aves, "Africa's long-standing preferential access to western markets offers 'back door' entry for some Chinese producers" 2) ascertain its belief that its development model is instructive for Africa; and 3) strengthen its diplomatic alliances essential to support its global ambitions (le Pere, 2008: 30). In other words, China's strategic incursion to Africa includes:

"the use of public diplomacy, including high-powered official visits and a triennial Forum on China-Africa Co-operation (FOCAC), 2) China's pledge of large amounts of aid and investments in Africa's infrastructure and other sectors with no political strings attached, except withdrawal of diplomatic relations with Taiwan, and 3) the use of aid donations to encourage Chinese companies to acquire overseas assets, such as oil and industrial raw materials so that Africa could become a strategic training ground for Chinese companies" (JETRO, 2007).

In addition to being diplomatic, the Chinese investment, trade, and infrastructural assistance help the African continent diversify its exports. But, it needs to be underlined that through government endorsed contracts, the Chinese EXIM Bank requires that in all overseas financing, the Chinese contract must ensure that they include export spin-offs in the long run from China. For instance, in the short run, while local and other foreign construction companies operate on profit margins of 15-25\%, Chinese companies usually operate on margins of under $10 \%$, making them extremely competitive. Large Chinese owned enterprises (SOEs) generally slice their profit margin to undercut other competitors. Despite the enormous challenges China faces concerning its own development, Beijing's focus on infrastructural development in Africa, with the construction of roads, bridges, hydroelectric and irrigation schemes, schools, hospitals, health centers and an array of government buildings, has driven private sector competition and made a clear and definite contribution to improving the lives of people across Africa (Corkin and Burke, 2008: 45). Africa needs to ascertain that the Chinese investments are transformative and are likely to extricate the African continent from the doldrums of underdevelopment. However, instead of mirroring Africa as a mere beneficiary of Chinese benevolence or as a renter continent, that is, the African state governments are recipients of the external rent and do not require a strong domestic sector, the Chinese cooperative assistance offers need to inspire alternative routes to an environmentally sensitive development based on a win-win strategic partnership.

Rocha declared that it is indisputable that China's engagement with Africa is producing positive results in the economic dimension of development. However, it is also clear that this engagement is not yet producing any meaningful impact in the lives of ordinary citizen. Instead of investing in its people and other productive activities, some countries are channeling the revenues generated towards unsustainable consumption patterns. Further, Africa's natural resources base and ecosystems are under continuous threat arising from an increase in exploitation activities. Under such circumstances, the "resource curse" is likely to fall upon some of the resource rich African nations (Corkin and Burke, 2008: 64). For example, in 2006, Angola signed with China for the construction of an oil refinery to enable Angola to meet increasing domestic demand and increase supply to regional markets with the Southern African Development Community. However, the negotiations broke down because instead of abiding by the intra-Africa trade, China insisted that the bulk of the refined oil be 
exported to China. Since China has not come out with environmentally sensitive programs, $30 \%$ of the forest logging concessions given to China in Central Africa is expected to precipitate an increase of carbon emissions. If the various mining concessions held by China in Africa do not comply with environmental laws, it is possible that they might be a health hazard and could impair human security. For instance in Gabon, the Chinese oil company was accused of "a whole range of unacceptable practices including pollution, exploding dynamite, and carving roads through parks. In addition, environmental and human rights groups, and businesses, are irked by some unsavory aspects of the Chinese profile, such as the deployment of Chinese labor, which limits local employment opportunities, destroys local manufacturing capabilities, and sustains poor labor and environmental standards" (JETRO, 2007). As articulated by Rocha:

"Since Cameroon, Congo, the Democratic Republic of Congo, Equatorial Guinea, Gabon, and Liberia are all major suppliers of timber to China, the conduct of industry in the Congo Rainforest has serious ecological and other implications for the entire continent. There are already indications that the effects of climate change will be most severe in Africa. Thus, continued mismanagement, in all its dimensions, of Africa's natural resources, renewable and nonrenewable, will have catastrophic consequences for the continent" (Rocha, 2008. 63).

On the other hand, some other African countries state that the presence of the Chinese in their countries is not only instructive but also contributes to positive spin-off, positive results. For example, Mr. G. D. Boateng, Executive Secretary at Ghana's Secretariat of the Chinese funded Bui Dam Project argues that "With Chinese assistance, old development plans that were jettisoned at the insistence of development partners are now being revived and are being executed at much lower costs. Before the Chinese came, the BUI Dam project had been on the shelf since the 1960s. We had expressions of interest from a number of Western companies in the 1960s and in 2001, but they all fell through because those companies didn't see the project as a worthwhile project. Now with Chinese assistance the project has gone off the shelf to the ground and this time it is an integrated project that includes the building of a new city around Bui" (JETRO, 2007). Also, in Lesotho, very important growth in the textile and clothing industry has been recorded as a result of investment from Asian firms. What is achieved in Lesotho "is the process of growth leading infrastructure as Chinese and Taiwanese investors demand improved infrastructure in transport, energy and water, all necessary for profitable operations in the sector" (Gelb, 2005).

On the whole, unlike the Western competitors, China makes no value demands that its aid be intertwined with investments and provides generous support for the expansion of Chinese companies into the African markets in order to diversify its source of supply for its industrial inputs. Based on this, a number of African governments seem to be satisfied with the Chinese contributions to the expansion of their infrastructure, tapping unexploited resources, integrating Africa's economies into global value chains, and visualizing China as a model for Africa's development. Despite the fact that domestic companies feel that they are being crowded out and there are shortfalls in the transfer of know -how and employment of local workers, a number of policy makers in Africa go one step further to justify that China has brought economic sanity to impoverished and conflict-ridden neighborhoods in Africa (Asche, 2008). To make China be influential and a credible source for Africa, a number of African countries have endorsed themselves to be a strategic training ground for Chinese stateowned enterprises, as well as private enterprises, in order to quench their thirst for oil and industrial raw materials (JETRO, 2007). Being the trailblazer from Western dictates, the Chinese ExportImport Bank has played a major role in low-cost financing development, cooperative projects, and coordinating the effort of Chinese state-owned corporations and private enterprises. 
Nevertheless, it is worth noting that the growth of South-South development cooperation in Africa is not likely to fundamentally change the terms of the relationship between Africa and the Western industrialized countries (North), but it can definitely be ascertained that the Africa continent has leveraging power to bargain with prospective Western investors (Gelb, 2005). The China-investment projects are in the process of generating development cooperation in resources, that is, (oil, mining, timber, agricultural commodities), trade and investment, and contracts for construction and engineering projects (roads, bridges, schools, shopping centers, housing and office buildings, water conservancy, and power plants) for Africa's present and future generations. Though very vital, African states thus far "have not developed strategies of their own that underpin their cooperation with China" (Asche, 2008). Therefore, if Africa is to extricate maximum benefits from its enhanced cooperation with China it needs to design its own game plan and allocate a specific role for China based on a common agenda at the continental level. Being engaged in constructive exchange, Africa simply needs to redefine the rules of the game to make it more amenable and less threatening to its own interests (Rocha, 2008: 55). For example, in South Africa, Chinese investments are "the product of lengthy and detailed negotiations that-apparently unlike some deals struck in other African settingsare framed in terms which conform to international legal norms and responsibilities" (Alden and Davis, 2006).

Due to limited cross-cultural communication, there seems to be lack of collaboration between the Chinese and African employees. The composition of the personnel in most of the over 800 stateowned Chinese firms, Africa seems to be dependent on Chinese experts. The Africans workers are busy accomplishing semi-skilled and manual types of work in textiles and clothing and the logging of tropical timber. The highly skilled and senior managerial personnel are brought from China and are mostly engaged in extractive industry (oil, gas, and mining), hydroelectric, and civil engineering. In addition, with Chinese infrastructure projects, local construction firms are crying foul with respect to Chinese bidding practices and with the overwhelming Chinese involvement in the composition of the semi-skilled labor force. This might be possible because the Chinese are not adequately trained in cross-cultural communication skills to effectively deal with their African counterparts. Even if the Africans are not highly trained in engineering and construction, as part and parcel of the Chinese codevelopment strategy, the main purpose of Chinese investment in Africa should have been to train and upgrade the skills of local personnel so that Africa could be in a better position to replace the highly skilled Chinese employees and investors in the near future. African governments should be in a position to monitor that the Chinese companies are contributing to improve the skills of the local workforce even if they may initially employ expatriate skilled technical and management personnel. Thus, the Chinese need to establish local educational infrastructure and provide training opportunities to adequately prepare the prospective African employees (UNDP, 2007).

Based the review of the literature, the socio-economic impacts of some of the Chinese cooperative investment in Africa are summarized using the following dimensions: a) local employment b) human management skills (control of decision making process), c) technological transfer, d) local content requirements, e) efficiency, and f) the terms of trade (See Table 1). The Chinese investors seem to be in control of decision-making and are involved as heads of the business functional areas (human development, accounting and finance, marketing, production and operations). Research and development ( $\mathrm{R}$ and $\mathrm{D}$ ) for all China-African investments are also controlled by state-owned enterprises and government-approved private agencies. Typically, state-owned companies arrive in Africa with their own work force, mainly project managers, engineers, technicians (Jian-Ye, 20070). Unless corrected, the China-African investment is likely to fatten the pockets of state elites and marginalize the African masses. In line with the objectives of the South-South Cooperation, the degree of control must 
be reversed if there is going to be technological transfers from China to Africa. Also, China has done little to integrate Africa into the global value chains. It is claimed that Chinese capital investments in Africa are new (Greenfield) rather than takeover investments. Chinese investments in Africa are constrained by not being environmentally friendly. Though an essential part of the technology transfer package, it is worth mentioning that a review of the literature shows that the China-African investments, similar to the Euro-African, have failed to handle Africa's negative environmental externalities.

\section{Table 1: Impact of Chinese Cooperative Investments in Africa}

\begin{tabular}{|c|c|}
\hline Indicator & Aggregate Analysis of the Effects of Chinese Investments in Africa \\
\hline Local employment & $\begin{array}{l}\text { In general, the Chinese are employed in highly skilled jobs where as } \\
\text { Africans are mainly engaged in lower skill jobs }\end{array}$ \\
\hline \multicolumn{2}{|l|}{ Human Capital } \\
\hline $\begin{array}{l}\text { Chief Executive officer/ } \\
\text { organizational structure }\end{array}$ & Mixed \\
\hline Accounting \& finance & Mixed \\
\hline Marketing & Local for local products \\
\hline Production and Operations & Mostly Chinese \\
\hline R\&D and Product Design & Mainly Chinese \\
\hline \multicolumn{2}{|l|}{ Technological transfer } \\
\hline $\begin{array}{l}\text { Engineering } \\
\text { Specification }\end{array}$ & Mostly accomplished by Chinese \\
\hline $\begin{array}{l}\text { Human Capital and Devel- } \\
\text { opment }\end{array}$ & Very minor training given to local employees \\
\hline Productivity & The China-Ethiopian firms are very productive \\
\hline Environmental Effect & Generally negative impact on the continent \\
\hline $\begin{array}{l}\text { Technological Infrastructure } \\
\text { for Backward and Forward } \\
\text { Linkages }\end{array}$ & Mixed impact \\
\hline Local Content Requirement & Less than $50 \%$ of supplies are obtained from domestic sources \\
\hline Efficiency & $\begin{array}{l}\text { Per unit cost of goods and services produced by the China-African } \\
\text { investment is cost effective }\end{array}$ \\
\hline Foreign Exchange & Mostly supplied by China's EXIM and China Development Bank \\
\hline International Marketing & Thus far, most of the products are sold in the domestic markets \\
\hline Boosting Exports & $\begin{array}{l}\text { Limited domestic manufactured products for the international market, } \\
\text { China heavily exports Africa's primary products }\end{array}$ \\
\hline Boosting Imports & $\begin{array}{l}\text { The Chinese have heavily flooded African markets with cheap and } \\
\text { poor quality products from China }\end{array}$ \\
\hline
\end{tabular}

(World Economic Forum, 2007; Asche, 2008).

African firms generally lose about 8 percent of sales due to power outages, and transportation delays account for about 3 percent lost sales (World Economic Forum, 2007). The Chinese construction companies are currently able to wind up to a third of all public tender processes in Africa to electrify 
a number of places and speed up the transportation process. The African governments see this as a means of obtaining construction services more cheaply and more quickly than obtaining them from Western construction firms. Nonetheless, it is instructive to notice that about 30 to 40 percent of the orders that come from China are being executed by Chinese firms, in collaboration with African local personnel and subcontractors (Asche, 2008). In 2006, Africa's exports to China were composed of oil and gas (about 62 percent), minerals and metals (about 13 percent), and manufactured goods ( 8 percent). The main imports of Africa from China included about 45 percent manufactured products, 31 percent machinery and transport equipment, and about 24 percent primary products. "Rough estimates suggest that Africa's terms of trade (the ratio of Africa's export price index to its import price index) in relation to China improved by 80 to 90 percent between 2001 and 2006 (Wang-Ye, 2007). More specifically, the terms of trade of the 48 Africa countries can be divided equally into winners (for example, oil exporting countries), winner-losers, and losers (oil-importing textile producers such as Madagascar and Mauritius, coffee producing and other agricultural exporting countries) (Kennan and Stevens, 2005).

While Chinese exports to Africa are poor in quality, they are generally cheaper to African consumers. The export driven strategy of China has contributed to huge job losses in a number of manufacturing industries throughout the African continent. For instance, instead of supporting domestic enterprises through backward and forward linkages within the domestic economy, the footwear industry in Ethiopia has been facing pressures from cheap Chinese imports (Gebre-Egzi, 2007). In addition, although cotton growers in West Africa have benefited from increased exports of raw cotton to China, "nevertheless most observers today share the concern that by purchasing raw materials from the continent and selling value-added products back, China's increased involvement will create unfavorable trade balance for many African countries" (Broker, 2007). The importation of Chinese manufactured textiles to Lesotho, Kenya, and South Africa with well established clothing industries has flared up social unrest and disruption by trade unions (Alden and Davies, 2006). As stated above, Chinese economic involvement on the African continent has contributed to a surge of low cost consumer goods. But, the importation of higher value-added products such as refrigerators, air conditioners, and other machinery products have not stimulated but displaced local products and laborers.

Efficiency, seeking and using local content inputs for export, oriented manufacturing Chinese investments have been very limited in Africa (United Nations, UNDP, 2007). "In recent the years Chinese entrepreneurs, often traders, have been traveling or migrating to Africa to seek business opportunities. Once established (teaming up with local business) in African towns, these entrepreneurs set up wholesale or retail outlets and import from China consumer goods like electronic appliances, textiles, and clothing, competing with local traders" (ECOWAS-SWAC/OECD, 2006). To summarize then, the internationalization of Chinese investment in Africa has been accelerated in recent years in manufacturing (textiles), resource extraction, construction and other services. China's incentives to promote FDI outflows to Africa take four forms: a) special and general tax incentives (All Chinese enterprises overseas are exempt from corporate income tax for five successive years after beginning operations); b) loans and credit (Chinese enterprises with investments abroad are accorded mediumand long-term commercial loans or soft loans from government-owned Chinese banks); c) foreign exchange (China's foreign exchange administration stipulates that Chinese enterprises are eligible for foreign exchange for foreign investment projects); and d) a favorable import and exports of raw materials and services (United Nations, UNDP, 2007). Based on the current Chinese investments and co-development projects existing in Africa critics argue that China is not only flooding the African markets with cheap consumer goods but also is devastating the local textile and other consumer product industries. In addition, they persuasively argue that as yet a) there is little evidence whether 
China's renewed, and most probably lasting involvement in Africa will serve the continent better than the decades of aid from Western governments, which have scarcely delivered on their promises; b) while Chinese FDI is contributing to economic growth (especially in resource-endowed states), apart from an infrastructure construction boom, "there is little evidence of a positive impact on broader human development" and c) "China has an African Policy. Africa doesn't have a China policy" (Broker, 2007; the daily newspaper Nation, 2006).

On the positive side, the supporters of Chinese investment in Africa argue "Africa registered 5.8 percent economic growth in 2007, its highest level ever, in part because of Chinese investment. Experts say the roads, bridges, and dams built by Chinese firms are low cost, good quality, and completed in a fraction of the time such projects usually take in Africa" (Hanson, 2006). In short, proponents of Chinese investment in Africa claim that China has not only provided assistance but has also invested in Africa in areas that the Western aid agencies and private investors have long neglected. For instance, though agriculture is regarded very vital for Africa's development, both the United States Agency for Development (USAID) and the World Bank reduced assistance to Africa's agriculture by as much as 90 percent in the 1990s. The Chinese state-owned enterprises, on the other hand, provided human and capital assistance to Africa without any conditionality (Lake and Whitman, 2006). Though instructive, the two diametrically opposed perspectives of the Chinese engagement in Africa deepen further research and analysis. For the last few years, Ethiopia has achieved a high and sustained rate of growth. Given the fact that Ethiopia has been the major beneficiary of Chinese investment and cooperative development projects, the question which needs to be pondered is therefore: can some of Ethiopia's spectacular growth rate be attributed to the Chinese investments? More specifically, have the Chinese cooperative investment footprints enabled the Ethiopian economy to master high valued technology and generate productive employment or have the various co-development Chinese investments deepen Ethiopia's economy on the Beijing consensus model?

\section{Conclusion}

Emerging discourse on the China-Africa relationship depicts China either as the new imperial power or as Africa's benefactor. In the West, reaction to China's involvement in Africa has bordered on suspicion and paranoia. Policy makers and analysts in the West are concerned that China could gain control over Africa's vast and untapped natural resources, particularly the continent's energy reserves. The current struggle over Africa's resources evokes worrying memories of an earlier scramble for pieces of the continent in the late nineteenth century by Western European powers and in the 1950s and 1960s by Eastern powers, principally China and Russia. China's involvement in Africa has serious implications for Africa and Africans. Instead of paranoia, this paper calls for guarded optimism regarding the deepening relationship between Africa and China. With China confident emergence on the global stage as the economic empire of the future, it would be ill advised for African leaders to turn their backs on the sleeping giant. However, while there is much that Africa could gain from the relationship, African leaders and Africans must guard against imperialism of any sort and shy away from arrangements that threaten sustainable development in the continent or undermine respect for human rights and human dignity. Most important, African leaders must push past Beijing's rhetoric of anti-hegemonism and develop clear policies to guide the continent's engagement with China. Drawing on the rich but sad lessons of tehnological scramble for Africa in the nineteenth century, African leaders must avoid the economic, political and legal pitfalls of the past and position the continent to benefit from strategic relations with their future partners. 


\section{REFERENCES}

Alden, C. (2005). “China in Africa.” Survival. 47 93: 147-164.

Alden, C. and Davis, M. (2006). "A Profile of the Operations of Chinese Multinationals in Africa." South African Journal of International Affairs, Vol. 13, Issue 1, Summer/Autumn 2006, 83-96.

Anshan, L. (2005). "African Studies in China in the Twentieth Century: A Historiograpghical Survey.” African Studies Review, 481.

Asche, H. (2008). “China's Engagement in Africa-Opportunities and Risks for Development.” Hamburg: Africa Department, Economics Affairs, 2008, p. 3.

China Comerce Yearbook, 2004, p. 615.

ECOWAS-SWAC/OECD (2006). "Africa and China Economic Series of the Atlas on Regional Integration in West Africa.” From http://www.atlas.estafrica.org

Ellis, Linden J. (2007). "China Exim Bank in Africa." China Environmental Forum, March 22, 2007. Woodrow Wilson Center for Scholars, From http://www.atlas.estafrica.org

GebreEgziabher, T. (2006). "The Developmental Impact of China and India on Ethiopia with Emphasis on Small Scale Footwear Producers.” Development Policy Research Unit, Johannesburg, South Africa (October 18 $-20,2006)$.

Gelb, S. (December 2005). "South-South Investment: The Case of Africa." Africa in the World Ecnomy-The National, Regional and International Challenges.

Gu, Jing and Humphrey, J. (2007). "The Impact of Africa on China." African Economic Research Consortium Working Paper No. ADWP-05. Retrieved October 31, 2008, from http://www.jcer.or.jp/eng/research /assia.html

Hamrin, C. L. Domestic Components and China's Evolving Three World Theory. Dover, MA: Auburn House Publishing Company, 1986.

Hanson, S. (June 6, 2006). “China, Africa, and Oil.” Council on Foreign Relations. Retrieved July 12, 2008 from http://www.cfr.org/publication/9557/

JETRO, April 26, 2007. Africapractice: The Impact of the Chinese Presence in Africa,

Isaac Idun-Arkhurst and James Laing (eds). London: Africapractice.

Jian-Ye, Wang (2007). What Drives China's Growing Role in Africa? Washington D.C: International Monetary Fund Working Paper, 07/211.

Kennan, J., and Stevens, C. (2005). "Opening the Package: The Asian Drivers and Poor-Country Trade." Sussex University: Institute of Development Studies.

Le Pere, G. (2008). "Prospects for A Coherent African Policy Response: Engaging China. New Impulses from the South: China's Engagement of Africa." Hannah Edinger, et al., eds. Centre for Chinese Studies, University of Stellenbosch, South Africa, 2008, 14.

Moss, T. and Rose, S. (March 29, 2007). "China's Export-Import Bank and Africa: New Lending, New Challenges, Centre for Global Development, Washington, D.C, 10.

Muekalia, D. J. (2004). “Africa and China's Strategic Partnership.” African Security Review, 13, no. 1: 5-1.

Rocha, J. (2008). "China and African Natural Resources: Developmental Opportunity or Deepening the Resource Curse?" Chinese Studies at Stellenbosch University, South Africa, p.58. 
Journal of Global Strategic Management | V. 3 | N. 2 | 2009-June | isma.info | 5-16 | DOI: 10.20460/JGSM.2009318457

The Broker (1 April, 2007). “China and Africa, How will the Beijing Consensus Benefit Africa?” From http:// www.thebrokeronline.eu/en/layout/set/print/articles/How-will-the Biijing-Consens...12/31/2008; The Daily Newspaper Nation, Nairobi, Kenya, 12.6.2006.

United Nations, UNDP, (2007). Asian Foreign Direct Investment in Africa: Towards a New Era of Cooperation Among Developing Countries. New York: United Nations, 2007.

World Economic Forum, 2007. Africa Competitiveness Report 2007 (Washington: World Bank), In http:// www.weforum.org/africacompetritiveness 